\title{
Az ELTE TÓK hallgatóinak testi-egészségi állapotának változásai az egyetemi évek alatt
}

\author{
Vitályos Gábor Áron ${ }^{1}$, Dancs Gábor ${ }^{2}$, B. Zsoffay Klára ${ }^{1}$, \\ Venyingi Beáta ${ }^{1}$, Darvay Sarolta ${ }^{1,3}$ \\ ${ }^{1}$ Eötvös Loránd Tudományegyetem Tanitó- és Óvóképző Kar Természettudományi Tanszék \\ ${ }^{2}$ Független kutató, Budapest, Magyarország \\ ${ }^{3}$ Selye János Egyetem Tanárképzö Kar Biológia Tanszék
}

\begin{abstract}
Absztrakt
Kutatásunk célja, hogy eredményeink alapján rávilágítsunk az egyetemi hallgatók életmódjának változására. Az ELTE TÓK hallgatóit az InBody 720 testösszetételanalizátor segítségével vizsgáltuk egyetemi tanulmányaik kezdetén, valamint tanulmányaik végének közeledtével. Az általunk végzett szemilongitudinális vizsgálat 2012 és 2018 között folyt 58718 és 25 év közötti női hallgató adatainak monitorozásával. A vizsgálati eredményekből kitűnik, hogy jelentős zsírfelhalmozódás történik a vizsgált időszak alatt: míg a fehérje-, a víz- és a sovány testtömeg változatlan maradt, addig a test összzsírtömege és az elhízás foka emelkedett. A felhalmozott zsírtöbblet testen belüli elhelyezkedése a belső szervek körül, a zsigeri zsír formájában mutatható ki, melynek mértékében a vizsgált időszakban jelentős növekedést regisztráltunk. Ezt támasztja alá a kerületi méretek és a hasi elhízás mértékének növekedése. A testtömegindex értékei ugyancsak változtak: a korábban a normális tápláltsági állapotúak közé tartozó hallgatók 3\%-a a túlsúlyos kategóriába került. Ezt a negatív irányú változást igazolja a fittségi index értékének változása is. A kapott eredményekkel szeretnénk felhívni hallgatóink figyelmét a mindennapos fizikai aktivitás és a helyes, egészséges táplálkozás fontosságára.
\end{abstract}

Kulcsszavak: testösszetétel, egészségi állapot, InBody 720 testösszetétel-analizátor, BMI

\section{Bevezetés}

Számos tanulmány kimutatta, hogy az egyetemi évek alatti életmód az egyetemi hallgatók egészségének negatív irányú változásához vezethet (Haase et al., 2004; Hussein et al. 2013; Ruiz et al., 2015).

Főként az első évek kifejezetten veszélyesek: a környezeti tényezők, mint a táplálék mennyisége és minősége, a napi tevékenységek, a fizikai aktivitás megváltozása, a stressz, a függőségek, mind hozzájárulnak a hallgatók korábbi életmódjának a megváltozásához (Rakovac, et al. 2013; Pedišić et al., 2014; Ruiz et al., 2015). 
A megváltozott életvitel, életkörülmények miatt kialakuló testtömegtöbblet, amely főként a zsigerek köré, közé lerakódó zsírtöbbletben nyilvánul meg, sokáig észrevétlen maradhat, de a későbbiekben számos, súlyossá váló betegség okozója lehet (Dietz et al., 2015; Hussain et al., 2013).

Ha megvizsgáljuk az Egészségügyi Világszervezetnek (WHO) a nem fertőző betegségek leküzdése érdekében létrehozott, az európai régióban 2025re vonatkozó akciótervét, láthatjuk, hogy a nem megfelelő táplálkozás helyreigazítása, illetve a fizikai aktivitás növelése jelentős helyen áll az előírt és elvárt változtatások között (WHO, 2016).

Azért tartjuk nagyon fontosnak a hallgatóink egészségi státuszának monitorozását, hogy felhívjuk a figyelmet a változások tényére és irányára, a prevenció jelentőségére, az egyén felelősségére saját egészségének megőrzésében (Vitályos et al., 2018).

Fontos, hogy hallgatóink mint a következő pedagógusnemzedék tagjai életvitelükkel követendő példát mutassanak a jövő generációi számára, elérve, hogy megteremtsük és megőrizzük a fenntarthatóság egyik alapkövét, az egészséget értékként elfogadó társadalom kialakulását.

Vizsgálatunk célja, hogy a kapott eredményeink megismertetésével próbáljunk hatni a vizsgált célcsoportra, ezzel elősegítve és támogatva a pozitív irányú változást.

De mit is értünk egészség alatt?

Az egyik legismertebb meghatározás szerint: „Az egészség a teljes testi, lelki, szociális jóllét állapotát jelenti, és nem csupán a betegség vagy fogyatékosság hiányát" (WHO, 1948).

Mára az egészség egy többdimenziós állapotként foglalható össze (Bárdos, 2013; Bárdos \& Kraiciné Szokoly, 2018):

- genetikai dimenzió (örökletes hiányok, örökölhető hajlamok),

- biológiai dimenzió (a szervezet egészének müködése, az egyes szervek müködése, valamint kölcsönhatásaik),

- lelki dimenzió (pszichés működés, lelki egyensúly minősége),

- mentális dimenzió (a gondolkodási folyamatok tisztasága),

- emocionális dimenzió (az érzelmek felismerése, átélése, kifejezési képessége),

- szociális dimenzió (az egyén kapcsolati rendszere, család, munkahely, társadalom),

- kulturális dimenzió (hagyományok, nézetek, elképzelések).

Fontos annak tudatosítása is, hogy a köznevelési és felsőoktatási intézmények jelentős szereppel bírnak a szociális és kulturális dimenziók formálásában, illetve az egyén szokásainak és életvitelének alakulásában.

A primer prevenció területén tűztük ki kutatásunk célját és feladatát, a hallgatók testösszetétel-vizsgálatát és a vizsgálatot követő, az eredményeket elemző személyes konzultációt. 


\section{Vizsgált személyek és alkalmazott módszerek}

A kutatás során 2012 és 2018 között vizsgáltuk az ELTE Tanító- és Óvóképző Kar első és utolsó éves hallgatóinak fizikai állapotát.

A vizsgált minta elemszáma $\mathrm{N}=587$ fö volt, melyet 18 és 25 év közötti női hallgatók alkottak.

A hallgatók tornafelszerelésben (rövidnadrág és trikó) vettek részt a vizsgálaton. Az InBody 720 típusú készülékkel végzett elemzésünket megelőzően, egy képzett szakember testmagasságmérést végzett (Sieber-Hegner antropometriai eszközzel) standardizált technikák szerint, az IBP ajánlásának megfelelően (Weiner \& Lourie, 1969; Bodzsár \& Zsákai, 2004).

A vizsgált személyek fizikai állapotát az InBody 720-as testösszetételanalizátor segítségével állapítottuk meg. A testösszetételt, a fittségi indexet, az elhízás fokát, a viszcerális elzsírosodás területét, a hasi elhízás fokát, a készülék automatikusan számolja. A számítás alapját képező képletek a készülék gyártója által védettek, nem hozzáférhetőek, ezért sem itt, sem a későbbiekben ezeket nem tudjuk feltüntetni.

A fittségi index esetében a készülék a következő kategorizálásokat végzi:

$<70$ - alacsony, az egészségi állapot rossz,

70-79,99- normál érték, az egészségi állapot megfelelő,

80-85 jó, az egészségi állapot jó,

> 85- nagyon jó, az egészségi állapot kitűnő (általában versenysportolókra jellemzö).

A tápláltsági állapot becsléséhez, az Egészségügyi Világszervezet által ajánlott testtömeg-indexet (body mass index - BMI) használtuk (WHO, 1995). A WHO szerinti határértékek, amelyekkel mi is dolgoztunk a vizsgálat során: $18,5 \mathrm{~kg} / \mathrm{m}^{2}$ alatt alultápláltság, $18,5-24,99 \mathrm{~kg} / \mathrm{m}^{2}$ normál tápláltság, $25-29,99 \mathrm{~kg} / \mathrm{m}^{2}$ túlsúly, míg $30 \mathrm{~kg} / \mathrm{m}^{2}$ felett elhízás.

A vizsgált testszerkezeti mutatókat és testösszetevő komponenseket a következő alapstatisztikai paraméterekkel jellemeztük: elemszám, átlag, átlag hibája, minimum, maximum és szórás (Hajtman, 1971). A különböző szempontok szerint képzett alcsoportok homogenitásvizsgálatát Student-féle kétmintás t-próbával ${ }^{1}$ (Hajtman, 1971), a hatásnagyságot a Cohen-féle d-értékkel vizsgáltuk (Cohen, 1988). Az elemzések során hipotéziseinket 5\%-os szignifikancia-szinten teszteltük az SPSS 20.0-as programcsomaggal.

\section{Eredmények}

A vizsgált változók alapstatisztikai mutatóit az 1. és 2. táblázat foglalja öszsze. A táblázatokban megjelenített paramétereket az InBody 720 készülék számolta. Ezeket az értékeket és számítási módokat a gyártó licence védi, az utóbbiakba nincs betekintésünk.

\footnotetext{
${ }^{1}$ Intervallumskálán mért változó esetén két csoport összehasonlítására.
} 
1. táblázat

A hallgatók $(N=587)$ bemeneti vizsgált testszerkezeti és testméretbeli, valamint élettani mutatóinak alapstatisztikai paraméterei

\begin{tabular}{|l|c|c|c|c|c|}
\hline \multicolumn{5}{|c|}{ BEMENET } \\
\hline & $\mathrm{V}_{\text {min }}$ & $\mathrm{V}_{\max }$ & $x$ & $\mathrm{SE}$ & $\mathrm{SD}$ \\
\hline Fittségi mutató & 48,0 & 90,0 & 72,6014 & 0,2116 & 5,1272 \\
\hline $\begin{array}{l}\text { Alapanyagcsere mértéke } \\
\text { (kcal) }\end{array}$ & 1040,0 & 1731,7 & 1304,0939 & 4,4071 & 106,7766 \\
\hline Elhízás foka (\%) & 71,8 & 187,9 & 103,2504 & 0,6501 & 15,7505 \\
\hline Testtömeg (kg) & 40,7 & 110,7 & 60,7746 & 0,4190 & 10,1515 \\
\hline Testzsírtömeg (kg) & 1,6 & 55,7 & 17,5312 & 0,2861 & 6,9318 \\
\hline Hasi elhízás foka & 0,72 & 1,04 & 0,8527 & 0,0021 & 0,0499 \\
\hline Jobb kar sovány tömege $(\mathrm{kg})$ & 1,27 & 3,44 & 2,0468 & 0,0147 & 0,3561 \\
\hline $\begin{array}{l}\text { Jobb kar sovány tömege } \\
\text { százalékban (\%) }\end{array}$ & 62,0 & 149,4 & 95,2566 & 0,5818 & 14,0971 \\
\hline Bal kar sovány tömege (kg) & 1,20 & 3,33 & 2,0170 & 0,0146 & 0,3529 \\
\hline $\begin{array}{l}\text { Bal kar sovány tömege } \\
\text { százalékban (\%) }\end{array}$ & 61,2 & 145,3 & 93,8668 & 0,5762 & 13,9592 \\
\hline Törzs sovány tömege (kg) & 13,74 & 27,09 & 18,7508 & 0,0915 & 2,2174 \\
\hline $\begin{array}{l}\text { Törzs sovány tömege } \\
\text { százalékban (\%) }\end{array}$ & 74,8 & 132,7 & 95,9259 & 0,3632 & 8,8007 \\
\hline Haskerület (cm) & 64,1 & 125,3 & 79,7496 & 0,3750 & 9,0858 \\
\hline Jobb felkarkerület (cm) & 22,6 & 43,0 & 28,4051 & 0,1129 & 2,7355 \\
\hline Bal felkarkerület (cm) & 22,5 & 42,8 & 28,2491 & 0,1126 & 2,7288 \\
\hline Sejten belüli víz tömege (kg) & 14,2 & 28,3 & 19,6129 & 0,0930 & 2,2526 \\
\hline Sejten kívüli víz tömege (kg) & 8,4 & 17,8 & 12,0322 & 0,0566 & 1,3703 \\
\hline Fehérjetömeg (kg) & 6,1 & 12,2 & 8,4792 & 0,0402 & 0,9741 \\
\hline Ásványi anyag tömege (kg) & 2,18 & 4,67 & 3,1185 & 0,0154 & 0,3732 \\
\hline
\end{tabular}

$\mathrm{V}_{\min }$ : minimum, $\mathrm{V}_{\max }$ : maximum, $x$ : átlag, $\mathrm{SE}$ : átlag standard hibája, SD: szórás 
2. táblázat

A hallgatók $(N=587)$ kimeneti vizsgált testszerkezeti és testméretbeli, valamint élettani mutatóinak alapstatisztikai paraméterei

\begin{tabular}{|l|c|c|c|c|c|}
\hline \multicolumn{7}{|c|}{ KIMENET } \\
\hline & $\mathrm{V}_{\min }$ & $\mathrm{V}_{\max }$ & $x$ & $\mathrm{SE}$ & $\mathrm{SD}$ \\
\hline Fittségi mutató & 44,0 & 89,0 & 72,2010 & 0,2404 & 5,8251 \\
\hline $\begin{array}{l}\text { Alapanyagcsere mértéke } \\
\text { (kcal) }\end{array}$ & 1046,4 & 1669,6 & 1311,1949 & 4,5466 & 110,1562 \\
\hline Elhízás foka (\%) & 72,3 & 192,0 & 104,6312 & 0,7198 & 17,4388 \\
\hline Testtömeg (kg) & 41,9 & 122,1 & 61,7978 & 0,4645 & 11,2533 \\
\hline Testzsírtömeg (kg) & 5,4 & 61,9 & 18,2245 & 0,3272 & 7,9272 \\
\hline Hasi elhízás foka & 0,75 & 1,10 & 0,8605 & 0,0023 & 0,0560 \\
\hline Jobb kar sovány tömege $(\mathrm{kg})$ & 1,23 & 3,45 & 2,0854 & 0,0155 & 0,3760 \\
\hline $\begin{array}{l}\text { Jobb kar sovány tömege } \\
\text { százalékban (\%) }\end{array}$ & 63,9 & 159,7 & 96,7387 & 0,6170 & 14,9485 \\
\hline Bal kar sovány tömege $(\mathrm{kg})$ & 1,23 & 3,38 & 2,0581 & 0,0153 & 0,3714 \\
\hline $\begin{array}{l}\text { Bal kar sovány tömege } \\
\text { százalékban (\%) }\end{array}$ & 63,5 & 145,9 & 95,4572 & 0,6067 & 14,6991 \\
\hline Törzs sovány tömege $(\mathrm{kg})$ & 13,65 & 27,52 & 18,9978 & 0,0963 & 2,3326 \\
\hline $\begin{array}{l}\text { Törzs sovány tömege } \\
\text { százalékban (\%) }\end{array}$ & 76,6 & 132,3 & 96,8610 & 0,3832 & 9,2850 \\
\hline Haskerület (cm) & 63,5 & 127,1 & 80,9063 & 0,4228 & 10,2444 \\
\hline Jobb felkarkerület (cm) & 22,5 & 44,6 & 28,7228 & 0,1258 & 3,0482 \\
\hline Bal felkarkerület (cm) & 22,5 & 44,3 & 28,5797 & 0,1258 & 3,0477 \\
\hline Sejten belüli víz tömege $(\mathrm{kg})$ & 14,2 & 27,2 & 19,7644 & 0,0959 & 2,3235 \\
\hline Sejten kívüli víz tömege $(\mathrm{kg})$ & 8,7 & 16,8 & 12,1341 & 0,0583 & 1,4122 \\
\hline Fehérjetömeg (kg) & 6,1 & 11,8 & 8,5440 & 0,0415 & 1,0060 \\
\hline Ásványi anyag tömege $(\mathrm{kg})$ & 2,20 & 4,46 & 3,1331 & 0,0159 & 0,3852 \\
\hline
\end{tabular}

$\mathrm{V}_{\min }$ : minimum, $\mathrm{V}_{\max }$ : maximum, $x$ : átlag, SE: átlag standard hibája, $\mathrm{SD}$ : szórás

A vizsgálatok azt mutatják, hogy az adott időintervallum alatt, a testtömegben abszolútértékében növekedés figyelhető meg. Ez a tömegnövekedés a testösszetevő-komponensek alapján, a következőképpen alakult: a fehérje, az ásványi anyag, a víz és a sovány testtömeg csak kisebb mértékben változott, viszont a testzsír változásában jelentős mennyiségű zsírtöbblettel számolhatunk. (1. ábra) 

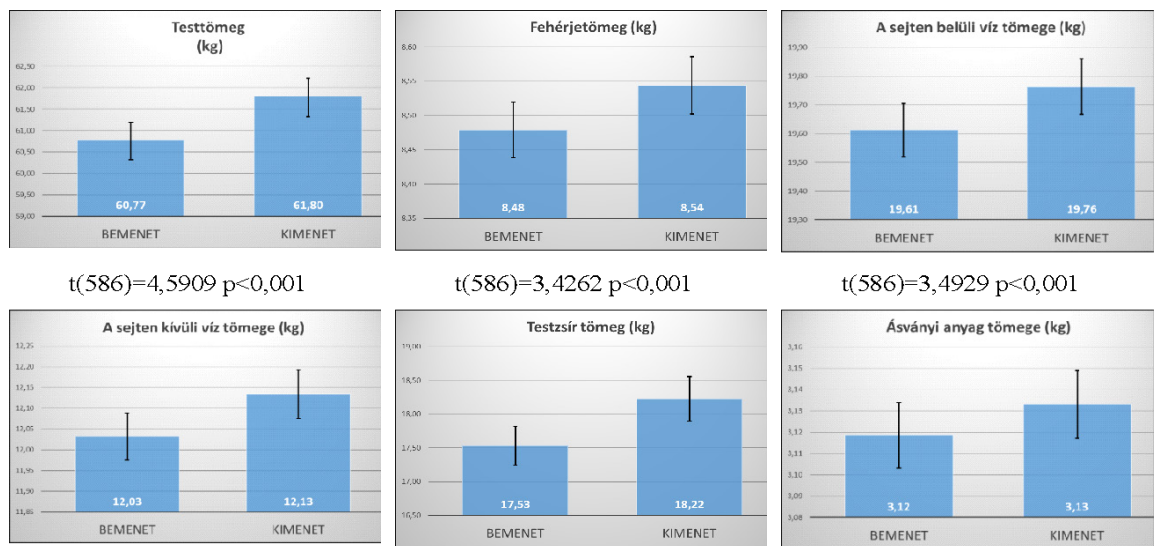

$t(586)=3,8949 p<0,001$

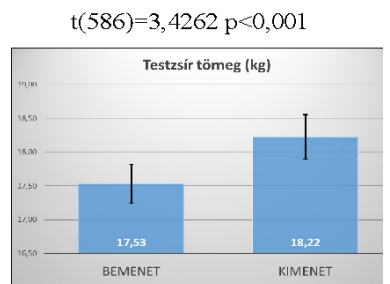

$t(586)=3,9900 p<0,001$

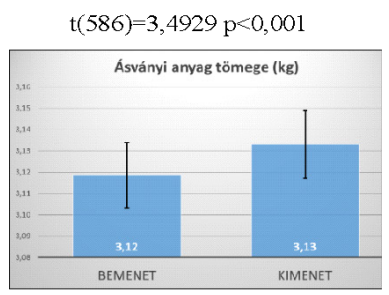

$\mathrm{t}(586)=2,2256 \mathrm{p}<0,005$

1. ábra

A bejövő és kimenő hallgatók testtömegében és testösszetételében történt változások

A testtömegindex változásainak elemzésekor azt tapasztaljuk, hogy a BMI értéke növekedett (2. ábra), és a tápláltsági állapot is változott: az alultápláltak és a normál tápláltsági állapotúak gyakorisága csökkent, míg a túlsúlyos és a kövér kategóriáknál enyhe növekedés volt megfigyelhető. (3. ábra)

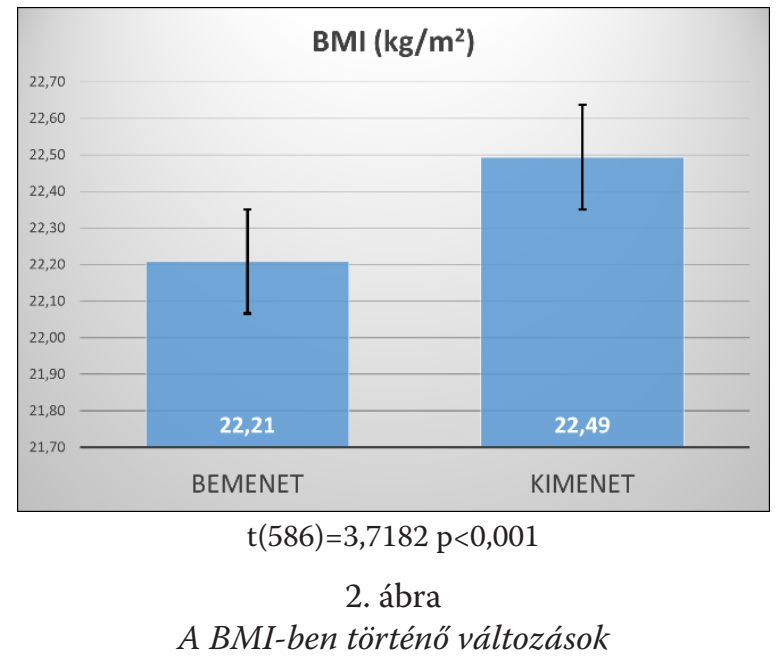




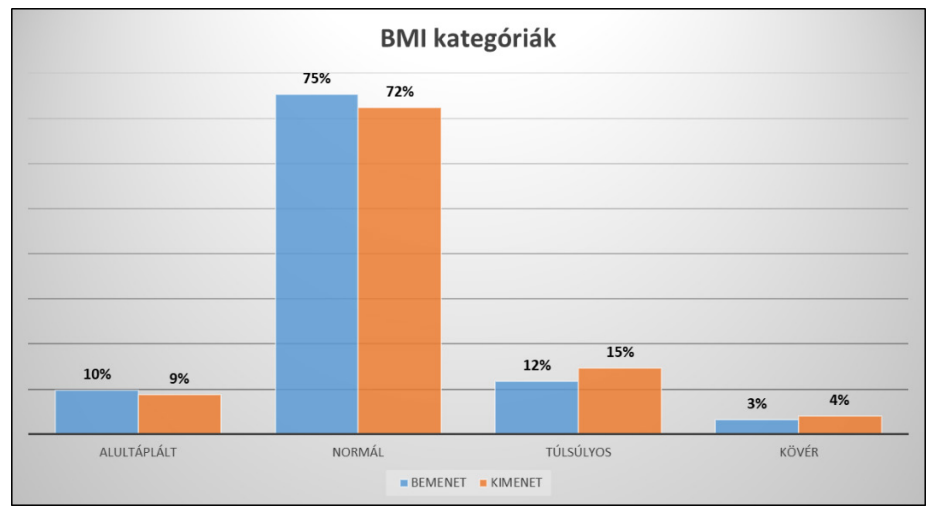

3. ábra

Változások a BMI kategóriákban

Az elhízás foka növekedett, különösen a hasi elhízásé, ami számos betegség kialakulásához vezethet. (4. ábra)

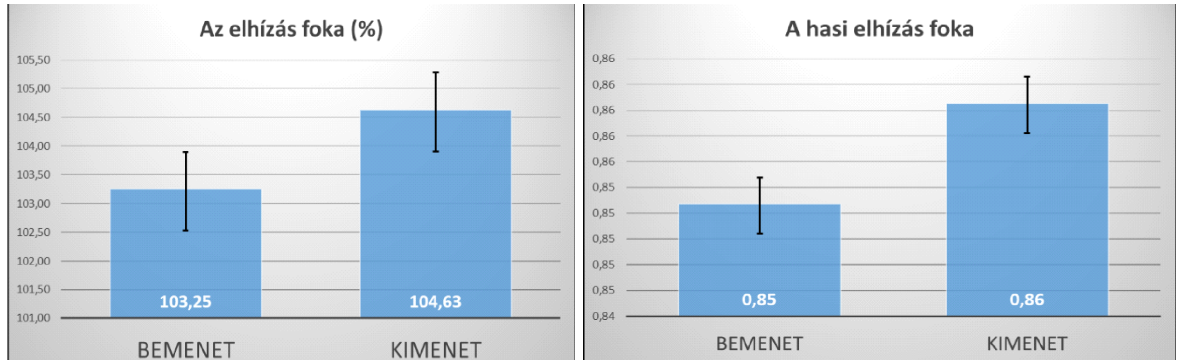

4. ábra

Változások az elhizás fokában

Mind a törzs, mind a felső végtagok, valamint a felsőtest teljes tömege jelentősen megnövekedett (5. és 6. ábra) és ezt az említett testrészek kerületi méreteinek növekedése is alátámasztja. (7. ábra) 

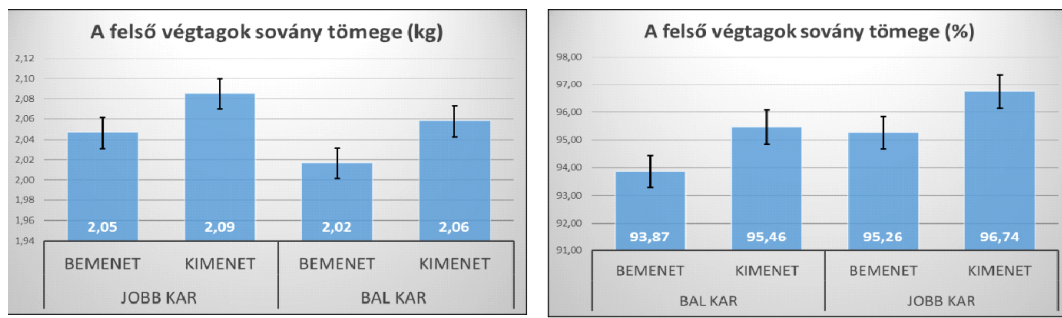

$\mathrm{t}(586)=4,7604 \mathrm{p}<0,001 \quad \mathrm{t}(586)=5,3311 \mathrm{p}<0,001 \quad \mathrm{t}(586)=4,6952 \mathrm{p}<0,001 \quad \mathrm{t}(586)=4,1774 \mathrm{p}<0,001$

Cohen's $\mathrm{d}=0,20 \quad$ Cohen's $\mathrm{d}=0,22$

5. ábra

Változások a felső végtagokon

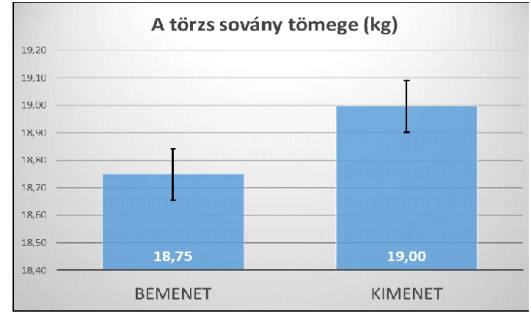

$\mathrm{t}(586)=5,1869 \mathrm{p}<0,001$, Cohen's $\mathrm{d}=$

0,21

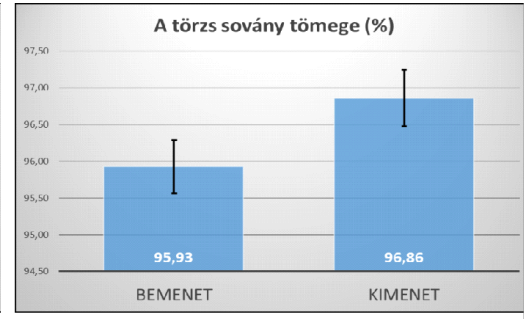

$t(586)=4,3260 \mathrm{p}<0,001$

6. ábra

Változások a törzsön

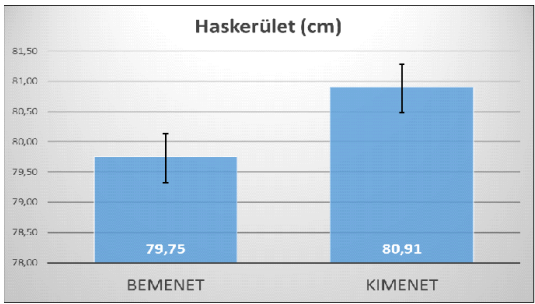

$t(586)=5,0083 p<0,001$

Cohen's $d=0,21$

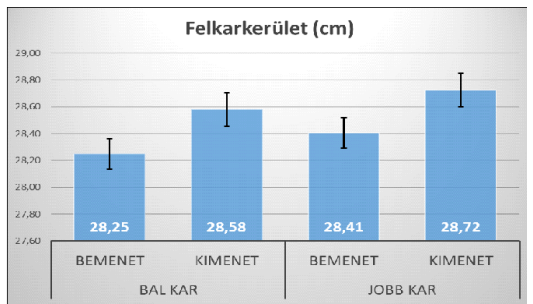

$t(586)=4,7962 p<0,001 \quad t(586)=4,6296 p<0,001$

Cohen's d $=0,20$

7. ábra

Változások a has-és felkarkerületben 
A fittségi indexben bekövetkezett változásoknál megállapítható, hogy a végzős hallgatóknál alacsonyabb értékeket találtunk, ami az érintett hallgatók esetében az egész szervezet egészségi állapotának romlását jelenti. (8. ábra)

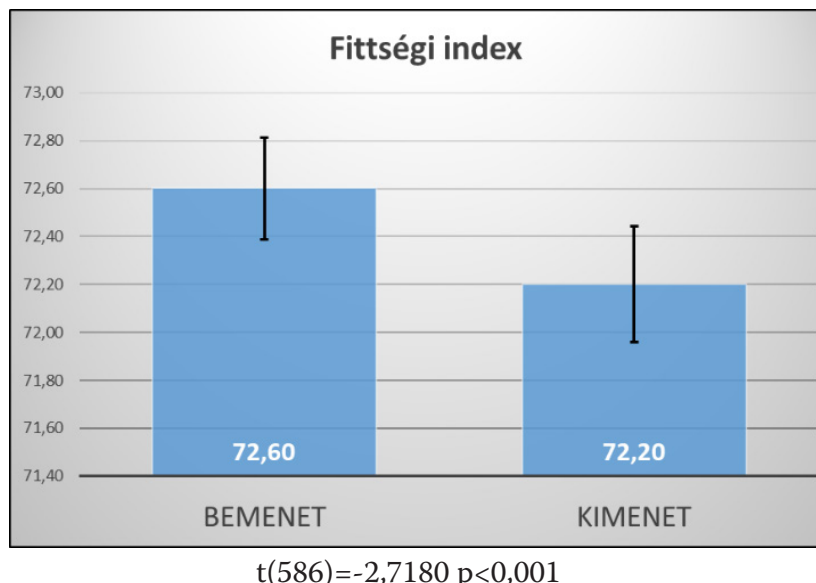

8. ábra

A fittségi index értékek változása

Az alapanyagcsere értékének növekedése a gyarapodott testtömegnek a következménye. (9. ábra)

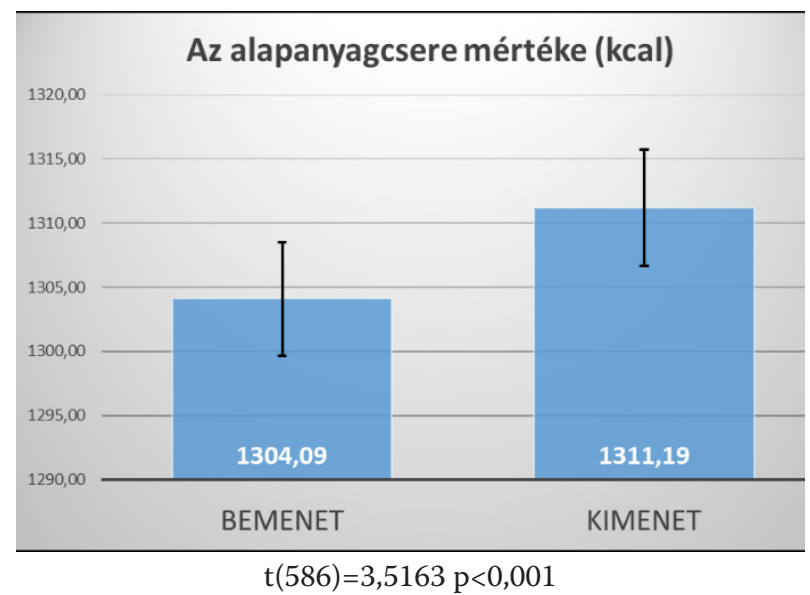

9. ábra

Az alapanyagcsere mértékének változása 


\section{Következtetések}

A hallgatók egyetemi évek alatti testösszetételének változásával több nemzetközi vizsgálat is foglalkozik, amelyek közül több - hasonlóan az általunk végzett kutatás eredményeihez - negatív irányú változást regisztrált (például Anderson et al., 2003; Pliner \& Saunders, 2008; Delinsky \& Wilson, 2008; Yahia, 2008; Gropper, 2012). Ezen vizsgálati eredmények alapján fel kell hívnunk a hallgatók figyelmét a rendszeres fizikai aktivitás és az egészséges étkezés fontosságára, egészségük megőrzése érdekében. Mindazonáltal a regisztrált esetek többségében az egyetemet kezdő hallgatók már eleve kevésbé aktív életmóddal rendelkeznek (Âcs et al., 2018). Ehhez társulhat az anyagi körülmények miatt is kevésbé egészséges étkezési szokások további kedvezőtlen átalakulása. Sajnos azt is tudjuk, hogy az egyetemi időbeosztás miatt életmódjuk nehezen egyeztethető össze az egészségvédő, tudatos életvezetéssel.

További vizsgálataink megvilágítják az egyetemi évek alatti különböző tényezők hatását az egészségre és a testösszetételre.

Azért tartjuk fontosnak, kutatási eredményeink széles körű megismertetését, mert ezzel szeretnénk elősegíteni, hogy hallgatóink nagyobb figyelmet fordítsanak egészségük megőrzésére, így később pályájuk során egészséges életet élő felnőttként, pedagógusként pozitív példát mutassanak környezetüknek, valamint a rájuk bízott gyermekeknek.

A kutatás rendelkezik az ELTE Tanító- és Óvóképző Kar Tudományos Bizottságának Kutatási engedélyével (2018/002), mely megállapítja, hogy az ELTE TÓK kutatásetikai elvei a jelen kutatás esetében maradéktalanul teljesülnek.

Köszönetnyilvánítás: A kutatási programban használt InBody 720 típusú műszer beszerzése a KMOP 4.2.1/B-10-2011-0002 pályázat keretében valósult meg.

\section{Irodalom}

Ács, P., Prémusz, V., Melczer, Cs., Bergier J., Salonna, F., Junger, J. \& Makai A (2018). Nemek közötti különbségek vizsgálata a fizikai aktivitás vonatkozásában a V4 országok egyetemista populációjának körében. Magyar Sporttudományi Szemle, 19(73), 25-31.

Anderson, D., Shapiro, J.R. \& Lundgren, J.D. (2003). The freshman year of college as a critical period for weight gain: an initial evaluation. Eating Behavior; 4(4), 363-367. https://doi.org/10.1016/S1471-0153(03)00030-8.

Bárdos, Gy. (2013). Munkastressz és egészség. „A rendvédelem és a honvédelem területén végzett orvosi és pszichológiai tevékenység kihívásai napjainkban". előadás BM-Dunapalota, 2013. november 7. 
Bárdos, Gy. \& Kraiciné Szokoly, M. (2018). Egészség, életmód, egészségfejlesztés a felsőoktatás szemszögéből. Neveléstudomány, Oktatás - Kutatás - Innováció. $7(2), 5-21$. https://doi.org/10.21549/NTNY.22.2018.2.1

Bodzsár, É. \& Zsákai, A. (2004). Humánbiológia. Gyakorlati kézikönyv. ELTE Eötvös Kiadó.

Cohen, J. (1988). Statistical Power Analysis for the Behavioral Sciences. Routledge.

Delinsky, S.S. \& Wilson, G T. (2008). Weight gain, dietary restraint, and disordered eating in the freshman year of college. Eating Behavior, 9(1), 82-90. https://doi.org/ 10.1016/j.eatbeh.2007.06.001.

Dietz, W.H., Baur, L.A., Hall, K., Puhl, .R.M., Taveras, E.M., Uauy, R. \& Kopelman, P. (2015). Management of obesity: improvement of health-care training and systems for prevention and care. The Lancet. 385(9986), 2521-2533. https://doi.org/10.1016/S0140-6736(14)61748-7.

Gropper, S., Simmons, K., Connell, L. \& Ulrich, P. (2012). Weight and Body Composition Changes during the First Three Years of College. Journal of Obesity, Article ID 634048. https://doi.org/10.1155/2012/634048

Haase, A., Steptoe, A., Sallis, J.F. \& Wardle. J. (2004). Leisure-time physical activity in university students from 23 countries: associations with health beliefs, risk awareness, and national economic development. Preventive Medicine, 39(1), 182-190.

https://doi.org/10.1016/j.ypmed.2004.01.028.

Hajtman, B. (1971). Bevezetés a matematikai statisztikába, pszichológusok számára. Akadémiai kiadó.

Hussain, R., Guppy, M., Robertson, S. \& Temple. E. (2013). Physical and mental health perspectives of first year undergraduate rural university students. $B M C$ Public Health, 13(1).

https://doi.org/10.1186/1471-2458-13-848

Pedišić, Ž., Rakovac, M., Titze, S., Jurakić, D. \& Oja. P. (2014). Domain-specific physical activity and health-related quality of life in university students. European Journal of Sport Science, 14(5)492-499.

https://doi.org/10.1080/17461391.2013.844861

Pliner, P. \& Saunders, T. (2008). Vulnerability to freshman weight gain as a function of dietary restraint and residence. Physiolgy \& Behavior, 93(1-2), 76-82. https://doi.org/10.1016/j.physbeh.2007.07.017

Rakovac, M., Pedisic, Z., Pranic, S., Greblo, Z. \& Hodak. D. (2013). Sociodemographic and Lifestyle Correlates of Health-Related Quality of Life in Croatian University Students. Applied Research in Quality of Life, 8(4), 493-509.

https://doi.org/10.1007/s11482-012-9203-9 
Ruiz, S., Nelia, M., Ontoso, A., Canga Armayor, I., Guillén-Grima, N., Hermoso de Mendoza, F., Serrano Monzo, H., \& Fernández, Blanca, M. (2015). Modificación del peso corporal de los estudiantes universitarios en Navarra durante los tres primeros años de universidad. Nutrición Hospitalaria, 31(6), 2400-2406.

https://dx.doi.org/10.3305/nh.2015.31.6.8686

Yahia, N., Achkar, A., Abdallah, A. \& Rizk, S. (2008). Eating habits and obesity among Lebanese university students. Nutrition Journal, 7, 7-32.

https://doi.org/10.1186/1475-2891-7-32

Vitályos, G. Á., Dancs, G., Bärnkopfné Zsoffay, K., Venyingi, B. \& Darvay, S. (2018). Egyetemi hallgatónők vérnyomásának, tápláltsági állapotának és életvitelének összefüggései. Anthropologiai Közlemények, 59 31-45.

https://doi.org/10.20330\%2FAnthropKozl.2018.59.31

Weiner, J.S. \& Lourie, J.A. (Eds., 1969). Human Biology. A guide to fields methods. Blackwell.

World Health Organisation (1948). Preamble to the Constitution of WHO as adopted by the International Health Conference, New York, 19 June - 22 July 1946; signed on 22 July 1946 by the representatives of 61 States (Official Records of WHO, 2, p. 100) and entered into force on 7 April 1948.

World Health Organisation (1995). Physical Status: The use and interpretation of anthropometry: Report of a WHO Expert Committe. Technical Report Series 854, WHO, Geneva. http://apps.who.int/iris/bitstream/10665/37003/1/WHO_ TRS_854.pdf.

World Health Organisation (2016). Plan for the Prevention and Control of Noncommunicable Diseases in the WHO European Region. WHO Regional Office for Europe. https://www.euro.who.int/_data/assets/pdf_file/0008/346328/ NCD-ActionPlan-GB.pdf. 


\section{Vitályos, G. Á., Dancs, G., B. Zsoffay, K., Venyingi, B. \& Darvay, S.}

\section{Somatical and health changes of students of ELTE TÓK during their university years}

The aim of our survey is to foster university students to change their unhealthy lifestyle. Students of ELTE TÓK were examined with InBody 720 body composition analyzer in the first and last year of their education. The semi-longitudinal survey was carried out from 2012 to 2018 with a sample of 587 female students aged between 18 and 25. Examination shows that the body mass significantly increased with fat surplus. Protein, mineral, water and lean body mass were unchanged; body fat mass and obesity degree increased. The placement of fat is interesting: visceral fat increasement is notable. That can be verified with their larger circumferences and increase of abdominal obesity degree. BMI also changed: students with normal nutritional status went to overweight category, their fitness score decreased. Results call our students' attention to the importance of physical activity and healthy nutrition.

Keywords: body composition, health status, InBody 720 body composition analyzer, BMI

Vitályos Gábor Áron: https://orcid.org/0000-0002-3965-0719

B. Zsoffay Klára: https://orcid.org/0000-0002-8841-4712

Venyingi Beáta: https://orcid.org/0000-0001-8934-0025

Darvay Sarolta: https://orcid.org/0000-0001-9862-015X 